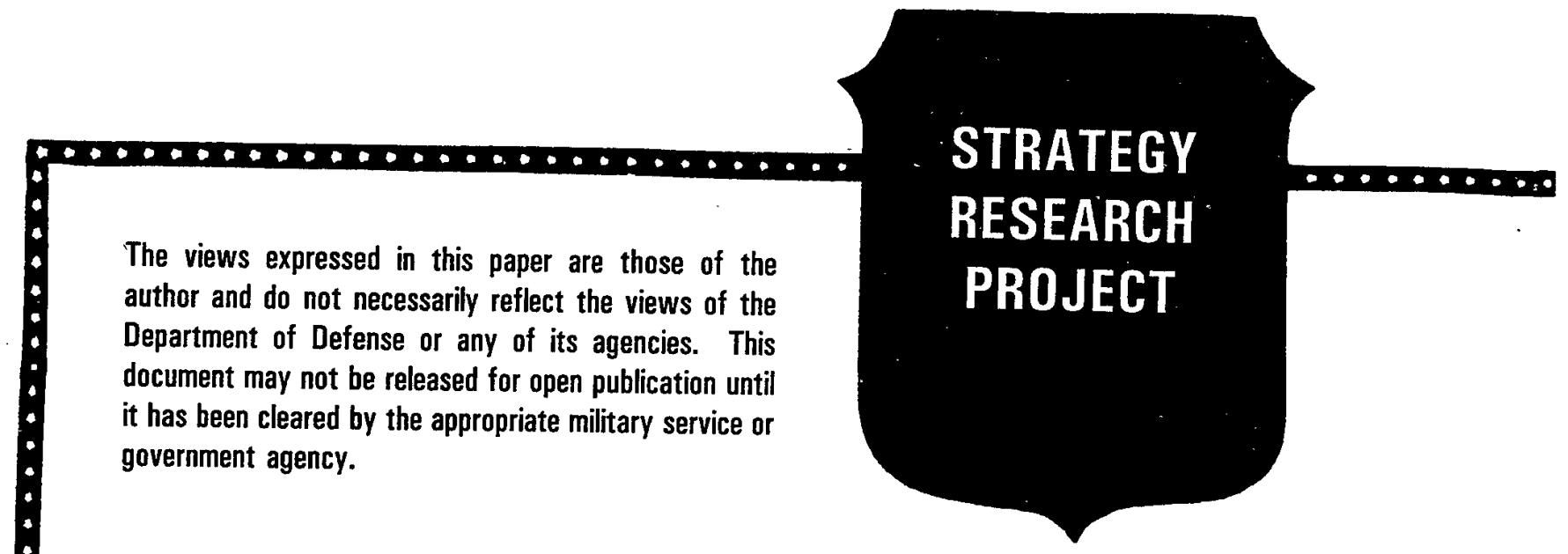

\title{
NATIONAL GUARD INVOLVEMENT IN COUNTERDRUG OPERATIONS AND ITS IMPACT ON READINESS
}

\section{BY}

\author{
LIEUTENANT COLONEL NICKEY W. PHHLPOT \\ DRUG ENFORCEMENT ADMINISTRATION \\ SSC Fellow \\ United States Army
}

\begin{abstract}
DISTRIBUTION STATEMENT A:
Approved for public release.

Distribution is unlimited.
\end{abstract}

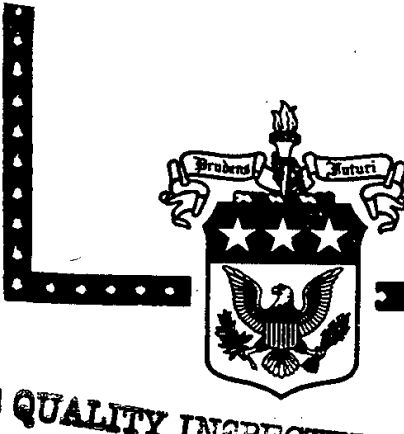

USAWC CLASS OF 1998

U.S. ARMY WAR COLLEGE, CARLISLE BARRACKS, PA 17013-5050 
USAWC STRATEGY RESEARCH PROJECT

\title{
National Guard Involvement in Counterdrug Operations and Its Impact on Readiness
}

by

LTC Nickey W. Philpot

\begin{abstract}
DISTRIBUTION STATEMENT A:
Approved for public

release. Distribution is

unlimited.
\end{abstract}

\author{
Colonel Jimmy D. Powell \\ Project Advisor \\ National Guard Liaison, DEA
}

The views expressed in this paper are those of the author and do not necessarily reflect the views of the Department of Defense or any of its agencies. This document may not be released for open publication until it has been cleared by the appropriate military service or government agency. 


\begin{abstract}
AUTHOR: Nickey W. Philpot (LTC), USA

TITLE: National Guard Involvement in Counterdrug Operations and Its Impact on Readiness

FORMAT: Strategy Research Project

DATE: $\quad 11$ MaY 1998 PAGES: 38 CLASSIFICATION: Unclassified

During recent years there has been a growing tendency to use the United States military in non-traditional ways in support of national strategies. One such initiative involving the military has been that of providing support to drug law enforcement agencies (DLEAs) in efforts to control illegal drug flow in the United States. The National Guard has become the primary agency for the Department of Defense in providing domestic support to DLEAs. Significant debate has been generated concerning how these domestic counterdrug efforts by the National Guard impact on readiness as the Guard continues to perform traditional federal and domestic missions. These questions are further amplified during this period of constrained resources and tendencies of the American public to call for maximum performance by the military at minimum cost. This paper offers a discussion of the National Guard Counterdrug Program and its impact on soldiers and airmen in their abilities to perform in primary military specialties.
\end{abstract}




\section{TABLE OF CONTENTS}

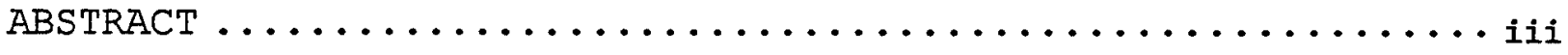

NATIONAL DEEENSE STRATEGY AND COUNTERDRUG SUPPORT ......... 1

AUTHORITY FOR THE NATIONAI GUARD COUNTERDRUG PROGRAM ........2

COMPONENT PROGRAMS OF NATIONAL GUARD COUNTERDRUG EFFORTS . . . . 10

IINGUISTIC SUPPORT $\ldots \ldots \ldots \ldots \ldots \ldots \ldots \ldots \ldots \ldots \ldots \ldots \ldots \ldots$

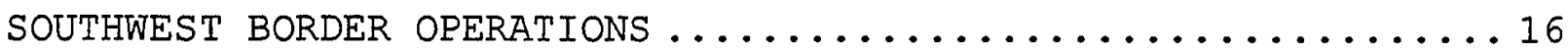

IISTENING POSTS/OBSERVATION POSTS ............... 16

SUPPORT TO THE U.S. CUSTOMS SERVICE .............. 18

ENGINEERING EFEORTS ....................... 21

AVIATION SUPPORT AND MARIJUANA ERADICATION ............. 24

CONCLUSION: CAPABILITIES AND CHALLENGES ............... 29

ENDNOTES .................................

BIBLIOGRAPHY $\ldots \ldots \ldots \ldots \ldots \ldots \ldots \ldots \ldots \ldots \ldots \ldots \ldots \ldots \ldots \ldots \ldots$ 
vi 


\title{
NATIONAL DEFENSE STRATEGY AND COUNTERDRUG SUPPORT
}

\begin{abstract}
As the United States moves into the next century being militarily ready means that U.S. forces must be prepared to conduct a broad range of military missions without being spread too thin. ... as well as sustaining a high level of training and morale and maintaining modern equipment and facilities. ${ }^{1}$
\end{abstract}

William S. Cohen

The past several years have yielded an intensified critical analysis and redefinition of our U.S. military's roles and missions. In pursuit of a safe and secure nation, it is increasingly important that our military forces and their associated missions be examined cautiously and with great fiscal constraint. Use of the military in newly emerging, nontraditional missions should be studied carefully and in close coordination with our nation's security strategy. It must remain clear that the primary reason for the existence of our military forces is to "fight and win" our nation's wars.

Clearly, there must be a great deal of attention, analysis, and discussion devoted to any mission that the Department of Defense (DOD) considers as possibly appropriate beyond the traditional "fight and win" focus. We must first ensure additional missions and expanded roles are designed to target specific threats to our national security, that our military has the means to counter the threat, and that the nation accepts and supports these new tasks for its military. 
The purpose of this discussion is to examine the involvement of the National Guard in our nation's drug control strategy through its counterdrug support program and the impacts of these programs on individual soldiers' and airmen's readiness posture while supporting both federal and domestic requirements. To fully grasp this complex subject, we must look at the legal authority and DOD rationale for the National Guard's involvement in the strategy as well as define how the Guard participates in the strategy through its involvement in 54 individual Governors' State Plans Programs. Additionally, it is imperative that this discussion be framed in the context of the impacts the program has on the full spectrum of capabilities that the Guard possesses.

The National Guard has historically been the component of the DOD with the closest links to our American communities. Located in all our nation's 54 states and territories, the National Guard is one of our country's most respected, trusted, and visible institutions. We must ensure that newly emerging roles for the Guard do nothing but support and enhance the Guard's traditional stature in American communities and further the national defense of our country.

\section{AUTHORITY FOR THE NATIONAL GUARD COUNTERDRUG PROGRAM}

The Constitution of the United States - as interpreted over 200 years - articulates the obligation of the federal government to uphold the public good, providing a bulwark against all threats, foreign and domestic. 
Illegal drugs constitute one such threat. Toxic, addictive substances present a hazard to society as a whole. ${ }^{2}$

The National Drug Control Strategy, 1997

DOD's involvement in the nation's illegal drug strategy can be understood by tracing its evolution from the beginnings of formal support arrangements to today's current policies and laws. The first formal acceptance of DOD support to the effort came when President Ronald Reagan signed the National Security Decision Directive (NSDD) in 1986, recognizing illegal drugs in the U.S. as a national security threat and asking Congress to consider an expanding role for the military in the national strategy. ${ }^{3}$ The NSDD was followed in 1986 by the first legislation that directly brought the DOD into the U.S. Counterdrug Strategy by appropriating $\$ 300$ million for DOD support. ${ }^{4}$ Then, in the Fiscal Year (FY) 89 Defense Authorization Act, Congress directed that the National Guard be provided up to $\$ 60$ million for state counterdrug efforts in support of drug law enforcement agencies (DLEAs) as part of the comprehensive DOD program. ${ }^{5}$

The National Guard, however, was already involved in counterdrug activities. As early as 1976, the Hawaii National Guard was supporting DLEAs in marijuana eradication efforts. By FY 87, 25 states had performed 376 missions with 1,547 personnel expending 8,883 man-days. ${ }^{6}$ The 1989 Defense Authorization Act brought these individual state initiatives under one national DOD 
program that would maintain the ability to provide military support at the local and state levels. Additionally, the 1989 Defense Authorization Act allowed for these missions to be resourced from a congressionally-directed account ensuring that other Guard and DOD programs would not become "bill-payers" for counterdrug missions. By June, 1989, many of the 54 states and territories had already submitted individual plans for their state's programs, and $\$ 40$ million was budgeted to execute those plans. ${ }^{7}$

The DOD and National Guard received authority to conduct counterdrug operations under Title 32 United states Code (USC) 112 that stipulates the Secretary of Defense (SECDEF) may provide resources through the Chief, National Guard Bureau, to states receiving SECDEF approval of their Governors' State Plans for National Guard Counterdrug Support. ${ }^{8}$ Title 32 USC 112 actually provides a good amount of detail as to the approval and resourcing for the Governors' State Plans.

The legislation prescribes fairly specific guidance as to the administration of the program. Appropriated funding must be used for both pay and allowances for personnel and operation and maintenance for equipment and facilities. Each of the 54 states and territories must submit to the SECDEF a Governors' State Plan specifying how many National Guard personnel are involved in the program, certification that the operations are conducted when personnel are not in federal status, that operations are in 
addition to traditional training requirements, and certifications by the governor and state attorney general that activities under the plan are authorized and consistent with state laws. Additionally, the law states that Guard personnel administering the program shall not be counted toward the annual end strength authorized for reserves on active duty. A ceiling of 4,000 members of the National Guard performing counterdrug duties in a Title 32 (state control) status is imposed. ${ }^{9}$

Taking the legal authority and guidance provided in Title 32 USC 112, the Departments of the Army and Air Force in conjunction with the National Guard Bureau (NGB), provide administration and program guidance for the Guard's Counterdrug Program in the National Guard Regulation (NGR) 500-2/Air National Guard Instruction (ANGI) 10-801. This regulation, which will be discussed later, provides overarching guidance for the Guard in dealing with supply and demand reduction operations as well as substance abuse programs including urinalysis testing for members of the National Guard.

Even though the DOD, to include the National Guard, has been involved in counterdrug operations both formally and informally for several years and is now sanctioned by law and regulatory guidance, debate continues as to whether these missions are appropriate for our nation's military. DOD, seeking to provide resolution to these questions, firmly speaks through secretary of Defense William S. Cohen's April, 1997, Annual Report to the 
President and the Congress, on this issue. Here he speaks clearly about the current DOD and U.S. strategic thinking:

The United States also has a key interest in countering the steady flow of narcotics into the United states from source countries in Latin America and the Caribbean.

Secretary Cohen goes on to state:

Supporting the national strategy has required that the United states maintain robust and versatile military forces that can concurrently accomplish a wide variety of missions ... operations include, among others, smaller scale combat operations, multilateral peace operations, counterdrug, counter terrorism, sanctions enforcements, noncombatant evacuations, and humanitarian and disaster relief operations. ${ }^{10}$

Cohen explains the DOD will offer support to DLEAs through five key mission areas: dismantling cartels, source nation support, detection and monitoring the transport of illegal drugs, direct support to DLEAs in CONUS, and demand reduction (both substance abuse and volunteer community outreach) . ${ }^{11}$

With the above SECDEF guidance, coupled with the Title 32 USC 112 language defining the Guard's Counterdrug Program, it appears to be appropriate for us to advance our discussions from a justification for the program to an analysis of how this involvement impacts on the readiness posture for the National Guard.

The DOD Coordinator for Drug Enforcement Policy and Support (OSD, DEP\&S) manages the entire DOD program and is responsible for both policy matters and fiscal management. Planning guidance 
is developed by this office, and SECDEF approval for the Governors' State Plans is coordinated here. ${ }^{12}$

The NGB's Counterdrug Directorate (NGB-CD) manages Guard specific programs that support the office of the secretary of Defense (OSD) Counterdrug Strategy. NGB-CD interfaces directly with each of the states providing policy guidance to them, managing financial accounts for the program, and planning for future Guard counterdrug initiatives.

Each of the 54 National Guard Counterdrug Programs are administered by a state counterdrug coordinator (CDC) who, in most cases, will be a lieutenant colonel or colonel from either the Army or Air National Guard. This individual is a Title 32 guardsman on active duty through the Active Guard-Reserve (AGR) program.

The CDC is responsible for coordinating Guard efforts in support of law enforcement for counterdrug operations. ${ }^{13}$ Under the provisions of NGR 500-2, it is the $C D C^{\prime}$ s responsibility to construct the Governors' State Plans and submit them through the NGB to OSD. ${ }^{14}$

The Governors' State Plans document is the single most important operational and management tool in the program. An entire FY is directed by the plan once approved by the SECDEF. Each plan presents a threat assessment for that particular state. Based upon that threat, the document prioritizes proposed missions and levels of support to DLEAs for that time frame. 
There are six approved mission categories that may be funded by the SECDEF in support of a Governors' State Plan. Again, Title 32 USC 112 and NGR 500-2 provide this authority and guidance. Additionally, each governor and state attorney general must certify that the plan's missions are not inconsistent or prohibited by state law.

Each SECDEF approved mission category is further divided into sub-missions. The following is a listing of approved mission categories and sub-missions that may be executed as defined by NGR 500-2: ${ }^{15}$

Mission Category \#1 - Program Management

Mission 1. Counterdrug Coordination, Liaison, and Management

Mission Category \#2 - Technical Support

Mission 2a. Linguist (Translator) Support

Mission.2b. Intelligence Analyst Support

Mission 2c. Operations/Investigative Case Support

Mission 2d. Communications Support

Mission 2e. Engineer Support

Mission 2f. Subsurface/Diver Support

Mission Category \#3 - General Support

Mission 3a. Domestic Cannabis Suppression/ Eradication Operations

Mission 3b. Transportation Support (aerial, ground, or maritime) 
Mission 3c. Maintenance/Logistical

Mission 3d. Cargo/Mail Inspection

Mission Category \#4 - Counterdrug-related Training

Mission 4. Training DLEA/Military Personnel

Mission Category \#5 - Reconnaissance/Observation

Mission 5a. Surface Reconnaissance

1. Unattended Sensor Support

2. Visual Reconnaissance/Observation - Listening Posts/Observation Posts (LP/OP)

3. Ground Surveillance Radar (GSR)

Mission 5b. Aerial Reconnaissance

1. Radars

2. Unmanned Aerial Vehicles (UAVs)

3. Aerial Visual Techniques, including Infrared/

Thermal Imagery, and Photographic

Reconnaissance

4. Photo Reconnaissance/Film Processing

Mission Category \#6 - Demand Reduction Support

Mission 6a. Community Based Demand Reduction Support

Mission 6b. Educational Institution Demand Reduction Support

Mission 6c. Informational Demand Reduction Support

Mission 6d. Leadership Development

Mission 6e. Coalition Development 


\section{COMPONENT PROGRAMS OF NATIONAL GUARD COUNTERDRUG EFEORTS}

As we examine the SECDEF approved mission listing for counterdrug support within the National Guard, we note that there are two key factors influencing state leadership as to how they will direct their efforts. The first is the individual threat that is present in a particular state. Each governor and attorney general will view a state's threat differently based largely on geographical location and concerns voiced by the local population. For example, in California and Texas, support to the U.S. Customs Service at land ports of entry (POES) is central to their respective states' threat (control of drug flow across the Southwest Border) and an issue of intense popular interest due to "quality-of-life" concerns in that region. In interior states such as Kentucky and Tennessee, however, support to the U.S. Customs service is not of as high a priority due to differing threats in those states.

The other critical issue that causes a state to focus in certain areas is the internal force structure of its National Guard. States that are "blessed" with soldiers and airmen possessing linguist specialties are naturally drawn to translation support missions. In states with strong army aviation programs, we tend to see thriving marijuana eradication efforts, due to the pronounced aerial reconnaissance requirements for that mission's success. 
Once the governor's intent is articulated through a detailed threat analysis and the mission selections of the plan, it is up to the Guard leadership to turn the plan into actual support to law enforcement.

Regardless of the types of support to DLEAs that the Guard may choose to provide, a state's counterdrug program represents an appreciable increase in resources for any state. Effective leaders traditionally search for opportunities to capitalize, in as many ways as possible, on resources provided to them. Most leaders view counterdrug resources and assets in much the same vein.

To fully grasp impacts of the program, we need to look at the historical funding amounts for the Guard's Counterdrug Program at the national level. Program funding has ranged from a "start-up" budget of $\$ 40$ million in FY 89 to a current budget of \$150 million for FY 98. FYs 93 and 94 were particularly "good" budget years for the program. The program was funded at $\$ 260$ and $\$ 209$ million respectively for those years. ${ }^{16}$

Again, the point must be made that this funding is totally separate and at no expense to traditional Guard programs. In other words, the operations and initiatives conducted as a result of these counterdrug funds offer additional man-days, equipment, and training opportunities for Guard personnel specifically to be used to support law enforcement in counterdrug functions. 
Title 32 USC 112 is very clear about the last statement; however, logic might suggest that many of the skills required in these roles to support law enforcement are the exact same skills that a "traditional" guardsman must possess in the performance of his assigned tasks as a traditional unit member of the National Guard. We must remember that all personnel that perform counterdrug duty will continue to hold a unit position and attend all regular unit training events to include annual training and required military schooling.

There are numerous component programs in the Guard's overall Counterdrug Program that allow traditional guardsmen to gain additional skills and practice that enhance performances of individuals in their primary military occupation specialty (MOS) or Air Force Specialty Code (AFSC). Aside from MOS and AFSC opportunities, we should not discount the various common soldier and airman tasks, as well as leadership skills that prove to be inherent in the performance of most military functions.

To illustrate this assertion, we shall look at three component programs that the National Guard conducts in support of its counterdrug efforts serving as examples representing the entire national program. The three programs that we will discuss are Linguist Support, Southwest Border Initiatives, and Army National Guard Aviation and Marijuana Eradication Support. These three programs by no means cover the entire scope of all the 
national efforts, but they will allow for specific analysis of several areas worthy of study.

\section{LINGUISTIC SUPPORT}

The Utah National Guard supports law enforcement throughout the country in the operation of its Joint Language Training Center (JLTC). The Utah National Guard, a reflection of the greater Utah population, is a "natural" in meeting this national need.

Utah is the most "linguistically" diverse region in the United states. Much of its linguistic abilities can be directly attributed to the efforts of formal training through the Mormon or Church of Jesus Christ of Latter-day Saints which focuses on the preparation and sending of young men and women on "missions" throughout the world. As a result of this intense effort, there is an abundance of language abilities in the state that the National Guard can access. ${ }^{17}$

The Utah National Guard operates two separate facilities providing transcription and translation support to federal and state DLEAs. ${ }^{18}$ Approximately 150 linguists possess the ability to provide support in over 30 languages. ${ }^{19}$ The support mostly entails listening to tape recordings and producing written transcripts, both in English and the "other" language, for law enforcement and court officials. ${ }^{20}$ 
The functions of the JLTC personnel appear consistent and in support of unit missions of the Utah National Guard. As with all Guardsmen on counterdrug duty, Utah personnel of the JLTC also hold traditional assignments within the Utah National Guard. They are required to meet all typical unit requirements including inactive duty training (IDT-weekend drills), annual training (AT), and professional education requirements.

Utah units providing personnel in support of the JLTC mission include the 300th Military Intelligence Brigade, 19th Special Forces Group, 169th Intelligence Squadron, and other Army and Air National Guard Units from throughout the state. ${ }^{21}$ As evidenced by these listed units, Utah's force structure requirements result in high demands for linguist-type specialties.

Information suggests that the additional training received through participation in the JLTC program enhances duty performance in traditional assignments. The standard, or baseline requirement, on the Defense Language Proficiency Test (DLPT) is 2 (listening) / 2 (reading) for a soldier with the $97 \mathrm{~L}$ (linguist) MOS. Of the 150 individuals in the JLTC Program, 103 have current DLPT scores of $3 / 3$ (highest possible score), $2+/ 3$, or $3 / 2+$. All officers and enlisted personnel, who are eligible (based on initial entry training) to be qualified in their Mos, have met the required standards. ${ }^{22}$ 
LTC Rickie C. Gurr is the "full-time" Brigade Administrative Officer for the 300th Military Intelligence Brigade in Utah. He is the officer tasked to represent the brigade commander, on a full-time basis, on all issues regarding training and readiness for the brigade. His assessments of the JLTC program are very positive. "These guys are the best linguists I've seen. They do it on a daily basis." He goes on to explain that not only are their linguist skills improved as a result of the program, but they also become better leaders because of their everyday exposure to the military. LTC Gurr adds that the facilities built to support the JLTC program in Utah have, in effect, become the best language lab available. ${ }^{23}$

The soldiers and airmen participating in the JLTC Program are judged by other available measurement criteria to perform well and appear highly motivated. Unit data demonstrates that these personnel consistently perform above average in areas such as IDT (drill) attendance, weapons qualification, and physical fitness standards. ${ }^{24}$ In viewing all of this information collectively, it appears that participation in the JLTC Program not only improves soldier and airman skill proficiency, but also positively impacts on the mastery level of basic military tasks. ${ }^{25}$ 


\section{SOUTHWEST BORDER OPERATIONS}

The National Guard Counterdrug Program along the Southwest Border is highly intensive. The National Guards of California, Arizona, New Mexico, and Texas share the common interest of shielding the United States of illegal drug flow from across this 2,000 mile border. Certain operations critical to this mission call upon soldiers and airmen to become very proficient at the use of common military skills that have application during any military activity. Other operations require specific military skills that demand high levels of technical knowledge and expertise. This discussion of Southwest Border operations will include attention to both types of skills as they apply to listening post (LP) / observation post (OP) operations, support to the U.S. Customs Service at land ports of entry (POEs), and engineering projects.

\section{LISTENING POSTS/OBSERVATION POSTS}

LP/OP operations conducted by the military along the Southwest Border have proven to be a great asset to DLEAs operating in those areas. While the federal armed forces (Title 10) are somewhat restricted by Title 18 USC 1385, the Posse Comitatus Act, the Guard is a bit more flexible in the support it may provide. The Guard, operating in a Title 32, non-federalized status, is not subject to the same restrictions of Title 18 USC 1385, making it better suited for certain kinds of domestic support missions. 
The Texas National Guard conducts LP/OP missions through their Counterdrug Special Operations Detachment (SOD). The SOD's primary mission is to conduct low visibility surveillance operations used to detect and report illegal drug activities in support of law enforcement interdiction operations. Secondly, the SOD provides training support to DLEAs in skills that will help them perform counterdrug duties in support of their operations. ${ }^{26}$

The Texas SOD performs LP/OP kinds of missions with personnel possessing infantry, scout, communications, ranger, and special forces backgrounds. Beginning its operations in 1985, the SOD's initial operations were along the Southwest Border. Since 1991, however, the SOD has expanded its capabilities to include LP/OP operations in urban environments as well. To date, the detachment has conducted over 250 missions in support of both state and federal DLEAs including various state authorities, the Drug Enforcement Administration, Federal Bureau of Investigation, U.S. Border Patrol, and U.S. Customs Service.

The Texas Counterdrug Program configures its SOD into "fiveman" teams capable of providing all-terrain support to DLEAs through 24-hour continuous surveillance.

Particularly impressive is the types of equipment the teams utilize during their operations. Using 35m photography and video cameras (mostly equipped with night vision capability), the teams have the ability to support DLEAs with retainable, "hard" 
data. Additionally, the teams use thermal imagery (both hand held and long range), UHF and VHF secure communications, and portable sensors. ${ }^{27}$

Beyond providing valuable support to DLEA personnel, much useful Mos enhancing training is provided to these "grunt" and "special operator" type individuals. Skills such as map reading and land navigation, mission planning, camouflage and concealment, first-aid, rappelling, and photography utilizing night vision devises are all components of the SOD's Mission Essential Task List (METL). ${ }^{28}$

SUPPORT TO THE U.S. CUSTOMS SERVICE

A key component of the Southwest Border strategy is the support that the National Guard provides to the U.S. Customs Service at the POEs along the U.S. - Mexican border. Although it is doubtful that any Customs official would term this support as anything less than critical to mission accomplishment, issues regarding readiness are frequently debated by both military and political leaders.

The basic problem stems from the argument that there is no MOS or AFSC that directly relates to skills required to support this mission. However, when a more detailed analysis is given of tasks associated with the mission, leadership and skill enhancements can be identified.

The cargo inspection team for the Texas National Guard at the Laredo POE is a component of the state's Task Force Guardian. 
The task force at the Laredo POE has 23 personnel assigned (19ARNG, 4-ANG). Task Force Guardian's mission statement asserts that they will assist the U.S. Customs Service in denying acts of illegal drug trafficking and providing for the seizure of illegal drugs and contraband crossing over the border into the U.S. at the border stations. This is a highly ambitious goal in Laredo since the station is only 150 miles from San Antonio and Corpus Christi, Texas, and Monterrey, Mexico, all of which are culturally diverse regions and large economic centers. The port consists of two motor vehicle bridges, an import lot, and a rail bridge.

The entire POE is open to traffic every day of the year. Texas Guardsmen work each of the areas and are continually present at the port. ${ }^{29}$

The majority of the work performed by Guardsmen at the port is hard, physical labor involving vehicle-by-vehicle cargo inspection. Evidence does suggest that certain basic common skills and leadership tasks are enhanced by these operations. Soldiers and airmen that are part of the task force operate as members of a military team that functions within a chain of command and works as a cohesive unit with a common goal. Noncommissioned officers supervise the planning and execution of continual operations under adverse and stressful situations. All personnel operate as members of the military on a full-time 
basis, making them much more adjusted to the requirements of military service. As stated earlier, the very nature of this work causes soldiers and airmen to maintain a high level of physical readiness. ${ }^{30}$

In addition to the above, members of Task Force Guardian receive specialized training on technical equipment that might possibly reinforce skills that relate to various specialties. Soldiers and airmen receive training on specialized equipment such as " $K-9$ Busters," instruments that measure density of suspected areas using gamma rays; "range. finders," devices that use laser beams to measure container lengths while searching for false compartments; and "mobile x-ray vans and trucks," equipment that can be relocated based upon requirements to assist in vehicle and cargo inspections. ${ }^{31}$ Application of these acquired skills may prove valuable beyond POE support as the military moves to further develop domestic support capabilities to civil authorities particularly in the weapons of mass destruction and counter terrorism areas.

Although it is difficult to express the value of this program in terms of readiness enhancements, there is no evidence that it detracts from any of the traditional missions that are undertaken by the Guard. Soldiers and airmen involved with the support to POEs are enthusiastic about the mission and appear to be highly motivated. ${ }^{32}$ U.S. Customs officials, at all levels, 
voice support for the program and praise the Guard for its efforts. Clearly, in an evaluation of the National Guard support to the U.S. Customs Service at POEs, all dimensions of the program must be studied as decision makers formulate long term strategies.

\section{ENGINEERING EFFORTS}

The third component of this discussion of National Guard support to the Southwest Border strategy deals with the various engineer projects that are in support of DLEA efforts in the area. These projects are executed by the California National Guard and coordinated with Joint Task Force (JTF) - 6. The tasking for this coordinated effort is to complete a road-fence network along the California sector of the Southwest Border to support the U.S. Border Patrol personnel operating there.

The project has resulted in a partnership between JTF- 6 and the California National Guard. JTF- 6 is charged by the DOD with the planning and coordination of active and reserve military assets, while in a federal (Title 10) status and supporting federal, state, and local drug law enforcement authorities. JTF6 serves as the planning headquarters for units participating in these kinds of operations.

Beginning in FY 96, JTF-6, in coordination with the active component, U.S. Army Reserves, and the National Guard, has managed a task force effort charged to construct roads and fences along the U.S. and Mexican Border. ${ }^{33}$ Important to note is that 
Guard units reporting directly to JTF-6 do so in an annual training status and rotate in and out of the project in two-week phases. These units may come from any state in the country, and their primary reason for participating in the project is as a training opportunity. Although the California Guard works closely with the JTF-6 operation and shares many of its goals, California troops report to the state's governor and are in a Title 32 status. Since the California National Guard participates under the authority of the Guard's Counterdrug Program, we will focus on them during this study.

The California National Guard organizes its support for this effort as "Team Engineer." Since 1990, Team Engineer has provided the Border Patrol with construction and maintenance support in road-fence projects. Border Patrol officials state that this support provides them increased abilities in navigating the border, managing vehicle and personnel flow in the area, and the seizing of illegal drugs. ${ }^{34}$

Team Engineer's work has been significant. They are responsible for constructing 13.58 miles of fence and 73.6 miles of new road. Additionally, the team is credited with improving another 191 miles of road.

Team Engineer is provided personnel assets from two engineer battalions and several Air National Guard Prime Beef Teams in California. ${ }^{35}$ Undoubtedly, these soldiers and airmen are given an abundance of opportunities to practice their "military trade." 
Captain Nick Ducich is the executive officer for Team Engineer as well as a traditional engineer company commander in California. He has a unique perspective and ability to comment about the training enhancement value that Team Engineer participation provides to engineering units throughout the state. Captain Ducich frames his comments in the context of personal observations:

As the executive officer for Team Engineer and an M-Day company commander, I have witnessed the benefits on multiple levels of soldiers working for the counterdrug program. The opportunities to the individual soldier are tremendous with respect to his/her professional development. The soldier improves his/her MOSQ and leadership skills daily while in the field or garrison. For instance, my company's equipment operators working for Team Engineer receive a minimum of six hours of stick time per day. The enlisted combat engineer soldier cross trains in other areas of engineering such as welding, concrete structures, and road design. The increase in instructor proficiency, military bearing, and quality training hours is dramatically influenced by the fifteen Title 32 soldiers in my company. ${ }^{36}$

Team Engineer has 132 individuals assigned with three commissioned officers, six warrant officers, and 123 enlisted soldiers ranging in rank from Master Sergeant (E-8) to Private (E-2). The team is composed of a headquarters, one maintenance, and three construction platoons. The dominate Moss within the team structure are the Engineer 12 and 62 series, as well as the Maintenance 63 series. However, other specialties such as food service, military police, aviation, medical, and administration are represented in the Team's composition. ${ }^{37}$ 
of all the various counterdrug programs, direct alignment between counterdrug positions and traditional unit assignments are most common here. Individuals are assigned to a Table of Distribution and Allowances (TDA) according to rank and MOS just as they are assigned to a similar position in a standard Guard unit. It is fairly easy to conclude that training under one assignment is highly beneficial to duty performance in the other position. In fact, this is the very reason that JTF-6, National Guard Bureau and USAR leadership determined it was appropriate for entire Guard and USAR units to support this program while conducting their most significant yearly training event, annual training.

The National Guard's strategy in providing support to DLEAs along the Southwest Border is dependent upon quality soldiers and airmen who are highly proficient at specific military skills. These personnel, through participation in various counterdrug programs, receive countless opportunities to practice and hone skills beyond the levels afforded traditional National Guard personnel. Additionally, DLEAs operating along the southwest Border are better able to focus their efforts and energies on countering the illegal drug threat while taking advantage of military expertise and resources.

\section{AVIATION SUPPORT AND MARIJUANA ERADICATION}

National Guard support in drug enforcement operations had its beginnings with marijuana eradication missions. For years 
the Guard has provided support in eradication operations in the form of both equipment and personnel. Essential is military aviation (helicopter) support due to heavy requirements for aerial reconnaissance. During this section, we will look at the marijuana eradication support program, both ground and air, and how it impacts on readiness in other mission requirements.

A typical Guard marijuana eradication team will be integrated into a larger DLEA team, bringing specific skills, equipment, and manpower into the effort. These resources are either not available to DLEAs or not there in sufficient quantities.

In most instances, a Guard team is composed of an aviation and ground support elements. The aviation element is normally composed of one or two pilots (depending on the type of aircraft); a mechanic; and, in most cases, a refueler. The ground element will consist of a team leader lofficer or senior noncommissioned officer), two-six (numbers will vary depending on the size of the operation) eradication personnel (enlisted), and a medical specialist (junior officer or noncommissioned officer). The aviation element will mostly be composed of Army National Guard personnel while the ground element is frequently a mixture of Army and Air National Guard personnel. The senior person on the team is designated as the officer-in-charge (OIC) and will coordinate his team's activities with senior DLEA personnel. ${ }^{38}$ 
Marijuana eradication operations provide numerous

opportunities for Guard personnel to practice their military skills beyond the scope of traditional assignments. A look at the aviation portion of the program and how it relates to the Army National Guard aviation program provides us with some useful data.

Oklahoma has a particularly robust Guard marijuana eradication program with four dedicated OH-58 aircraft, three full-time pilots, and two mechanics permanently assigned to these duties. Furthermore, there are plans to hire two additional pilots and another mechanic for the program during FY 98 . In addition to the state's dedicated marijuana eradication aviation assets, during the peak marijuana producing season for Oklahoma, the Guard will assign three-four more aircraft with crews and mechanics to eradication duty. ${ }^{39}$ The entire program is resourced using counterdrug program dollars and flight hours.

In FY 97, the Oklahoma Counterdrug Program utilized 1,390 hours; and in FY 98, projections are that the program will execute another 1,340 hours. ${ }^{40}$ In Oklahoma, these hours represent close to a $20 \%$ increase in their Army Aviation Flight Hour Program during those FYs. ${ }^{41}$

Marijuana eradication operations for aviation crews are basically compatible with the Army's Aircrew Training Manual tasks. Aviators, when taking part in eradication operations, practice skills such as low level navigation, reconnaissance, 
sling loading, rappelling, maintenance, night flying, and security operations. Safety procedures such as risk management and crew endurance are intensely exercised during "real-world" missions. ${ }^{42}$

The dedicated counterdrug aircraft brings an additional enhancement in capabilities to the Oklahoma Guard. The OH-58s are equipped with radios that have the ability to communicate with DLEA officials on their internal communications networks. These $\mathrm{OH}-58 \mathrm{~s}$ are also equipped with additional thermal imagery equipment making the aircraft not only well suited for advanced surveillance and reconnaissance missions, but also invaluable as a search and rescue platform.

These two capabilities greatly enhance the Guard's ability to interact and provide support during other domestic missions requiring interaction with DLEAs. For example, during the Oklahoma City bombing incident in 1995, two of the Guard's counterdrug $\mathrm{OH}-58 \mathrm{~s}$ were brought into state active duty status (funding provided by state sources) to support this response effort. ${ }^{43}$

Army Guard aviation support, however, is only a portion of the total eradication program. As mentioned earlier, the other aspect of the program is the ground element. The ground element is where the object of all eradication efforts are focused and realized. These individuals are responsible for coordination with aviation assets as well as the locating, cutting, and 
destroying of seized marijuana plants. The ground element provides the DLEA coordination, command and control, muscle, and medical support that ultimately produces mission accomplishment. Throughout.an operation, soldiers and airmen are presented opportunities to practice MOS / AFSC, common, and leadership skills. Individuals possessing differing MOSs and AFSCs bring needed skills to these types of missions. Medical skills are tasked heavily during summer-time, rough-terrain operational environments. Bee stings, heat injuries, and broken bones are not at all uncommon during these missions.

Combat arms personnel are preferred for the "cutters" positions. These individuals are utilized not only for their physical strength abilities, but also for land navigation, weapons maintenance, counter-booby trap, and camouflage and concealment skills. These types of skills are primary ones for success as an infantry-type soldier; however, other combat and support personnel need this type of basic military skill training as well. In fact, it may even be a greater enhancement for support personnel because they seldom get to practice these activities in their traditional unit assignments.

Junior commissioned and noncommissioned officers are afforded opportunities to gain experience at basic military leadership and planning skills. Operations orders, logistical planning, command and control, and rules of engagement are routine components of any eradication operation for a junior 
leader. These tasks, associated with a live threat environment, serve to stress young leaders in a way that is difficult to replicate in a training environment. ${ }^{44}$

As with other facets of the counterdrug program, marijuana eradication offers Guardsmen the chance to take their basic military skills and focus them in non-traditional ways while providing for domestic security. The eradication personnel gain additional experience in both ground and air operations that they can transfer to future military experiences regardless of specific mission requirements.

\section{CONCLUSION: CAPABILITIES AND CHALLENGES}

America's Army has changed significantly to meet the challenges of our uncertain world. An understanding of the evolving international environment, the national security strategy, and the capabilities required for full spectrum dominance have guided the Army's transformation from a Cold War, forward deployed force, to a capabilities-based, power projection force based largely in the United States. ${ }^{45}$

As articulated by the Secretary and the Chief of Staff of the Army in their FY 98 Army Posture statement that is quoted above, the period since the late 1980 s has been one of remarkable change for the Army and all of the DOD. Political, economic, and social changes have dictated that our leaders and strategic thinkers "re-shape" our national and military strategies to meet the demands of the current environment.

The Secretary and the Chief of Staff of the Army believe that our modern forces will be mostly maintained in the U.S., but 
must be a "capabilities-based and power projection force," and have the ability to operate with "full spectrum dominance." These are awesome goals that will require no less than a total DOD commitment by leveraging every program, from all the services, to mutually support each other in terms of resourcing, training, and actual operations.

The U.S. Congress took great care, when formalizing the National Guard's Governors' State Plans Program as a component of the larger DOD Counterdrug Program, to ensure all efforts in this area would be totally self-supporting and would not be at any expense to readiness and training programs already in existence. With stated Congressional intent, the DOD and National Guard have been successful in formulating a self-sustaining program. However, this discussion of the Guard's Counterdrug support efforts has demonstrated that soldiers and airmen are given countless opportunities to practice and improve upon military skills ranging from the very basic to the very technical in nature. Furthermore, the Guard's participation in counterdrug activities has allowed soldiers and airmen to build on traditional military skills with innovative technologies making them more capable of providing support to civil authorities in various types of domestic missions. These "value-added" qualities of the program not only assist the National Guard in the performance of its federal missions, but greatly improve the 
Guard's abilities to respond to various domestic needs for the country.

It is important that our long-range "thinkers" take note of the opportunities available through the military's support to the national counterdrug strategy. Here, the military is not only providing a direct service to the country and ensuring for national security, but also personnel skills along with required resources are expanded making soldiers and airmen more "capable" of participating in that "full spectrum dominance." 


\section{ENDNOTES}

1 William S. Cohen, Annual Report to the President and Congress, (Washington D.C.: U.S. Government Printing Office, 1997), 2 .

2 Office of National Drug Control Policy, The National Drug Control Strategy, 1997, Executive office of the President, (Washington D.C.: U.S. Government Printing Office, 1997), 3.

3 Michael H. Abbott, "The Army and the Drug War: Politics or National Security?" Parameters Vol. XVIII No. 4 (Washington D.C.: U.S. Government Printing Office, 1988), 95-112.

4 Don Armington, Mike Goodman, Craig Nicholson, Phil Spence, Darald Stebner, National Security Policy: The Role of the Department of Defense In the War on Drugs, (National Security Program Discussion Paper, John F. Kennedy School of Government, Harvard University, 1989), 15.

5 Ibid., 98 .

6 Ibid., 101.

7 Ibid., 102.

8 Headquarters, Departments of the Army and Air Force, National Guard Regulation (AR) 500-2 Emergency Employment of the Army and other Resources National Guard Counterdrug Support, (Washington D.C., Departments of the Army and Air Force, 1997), 3.

9 United States Code, Title 32, Section 112, (1998).

10 William S. Cohen, Annual Report to the President and Congress, (Washington D.C.: U.S. Government Printing Office, 1997), 4-5.

11 Ibid., 10.

12 Headquarters, Departments of the Army and Air Force, National Guard Regulation (AR) 500-2 Emergency Employment of the Army and Other Resources National Guard Counterdrug Support, (Washington D.C., Departments of the Army and Air Force, 1997), 4-5.

13 Ibid., 4-5. 
14 Robert J. Newberry, Department of Defense Coordinator for Drug Enforcement Policy and Support, Memorandum, "Preparation of Fiscal Year 1999/2000 National Guard Counterdrug Governor's State Plans and Other National Guard Programs", Washington D.C., February, 1998.

15 Headquarters, Departments of the Army and Air Force, National Guard Regulation (AR) 500-2 Emergency Employment of the Army and Other Resources National Guard Counterdrug Support, (Washington D.C., Departments of the Army and Air Force, 1997), 5-7.

16 NGB-CD Budget Briefing Slide, November, 1997.

17 Sally B. Donnelly, "The State of Many Tongues," Time, vol. 139, no. 15, (April 13, 1992), 51.

18 Joint Language Training Center Operations Briefing, Utah National Guard, Draper, UT, October 21, 1997.

19 Joint Language Training Center Information Paper, Utah National Guard, Draper, UT, October 21, 1997.

20 Joint Language Training Center Operations Briefing, Utah National Guard, Draper, Utah, October 21, 1997.

21 Ibid.

22 Joint Language Training Center Information Paper, Utah National Guard, Draper, UT, October 21, 1997.

23 Utah's Joint Language Training Center Interview with Lieutenant Colonel Rickie C. Gurr, 300th MI Brigade, Draper, UT, october, 1997.

24 Joint Language Training Center Information Paper, Utah National Guard, Draper, UT, October 21, 1997.

25 Utah's Joint Language Training Center Interview with Major Paul Harrell, Training Administrator, Utah Army National Guard, Draper, UT, October, 1997.

26 Texas National Guard Counterdrug Special Operations Detachment Briefing, Austin, TX, November 20, 1997.

27 Ibid. 
Ibid.

29 Texas National Guard Counterdrug Information Booklet, Task Force Guardian, Laredo, TX, undated.

30 Texas National Guard Port of Entry Operations Interview with LTC Gladys Tinsley, Austin, TX, November 18, 1997.

31 Texas National Guard Counterdrug Program Information Paper, Austin, TX, February 17, 1998.

32 Personal Observation and Discussions with Texas National Guardsmen assigned to Task Force Guardian, Laredo, TX, November $20,1997$.

33 William S. Mendel, Murl D. Munger, Strategic Planning and the Drug Threat, (Strategic Studies Institute, U.S. Army War College, 1997), 49-50.

34 California National Guard Planning Conference Booklet, San Diego, CA, February 5, 1997. 1998 .

35 Team Engineer Information Paper, Campo, CA, February 11,

36 Memorandum addressed to the author, Subject: Information on Title 32 Soldiers, From: Captain Nick Ducich, Commander, C Company, 578th Engineer Battalion (Heavy), Brawley, California, February 12, 1998.

37 Team Engineer TDA, Campo, California, February 12, 1998.

38 Interview with Colonel Chester M. Waggoner, Tennessee National Guard Counterdrug Coordinator, February 19, 1998.

39 Interview with Colonel Leroy A. Wall, Oklahoma Army National Guard Aviation Officer, October 23, 1997.

40 NGB-CD Flight Hour Mission Data Chart, NGB-CD Army Aviation Data Base, Undated.

41 Interview with Colonel Leroy A. Wall, Oklahoma Army National Guard Aviation Officer, October 23, 1997.

42 Ibid. 
43 Ibid.

441997 Tennessee Marijuana Eradication Overview Briefing presented by Captain Alisa Watts, Tennessee Army National Guard, February 20, 1998.

45 Togo D. West, Jr., Dennis J. Reimer, A Statement on the Posture of the United States Army Fiscal Year 1998, (1997), 13. 


\section{BIBLIOGRAPHY}

Abbott, Michael H. "The Army and the Drug War: Politics or National Security?" Parameters. Vol. XVIII No. 4: 1998.

Armington, Don; Mike Goodman; Craig Nicholson; Phil Spence; and Donald Stebner. National Security Policy: The Role of the Department of Defense in the War on Drugs: John F. Kennedy School of Government, Harvard University, 1989.

California National Guard Counterdrug Program Planning Conference Booklet. San Diego, California: 1997.

California National Guard Counterdrug Program (TEAM Engineer) Information Paper. Campo, California: 1997.

California National Guard Counterdrug Program (TEAM Engineer) Table of Distribution and Allowances. Campo, California: 1998.

Cohen, William S. Annual Report to the President and Congress. Washington D.C.: U.S. Government Printing Office, 1997.

Donnelly, Sally B. "The State of Many Tongues," Time Vol. 139 No. 15 (October) : 1992.

Ducich, Nick. Memorandum to the Author, Subject: "Information on Title 32 Soldiers." Brawley, California: 1998.

Headquarters, Departments of the Army and the Air Force. National Guard Regulation (AR) 500-2 Emergency Employment of the Army and Other Resources National Guard Counterdrug Support. Washington D.C.: Departments of the Army and Air Force, 1997.

Joint Language Training Center, Utah National Guard Information Paper. Draper, Utah: 1997.

Joint Language Training Center, Utah National Guard, Interview with Lieutenant Colonel Rickie C. Gurr. Draper, Utah: 1997.

Joint Language Training Center, Utah National Guard, Interview with Major Paul Harrell. Draper, Utah: 1997.

Joint Language Training Center, Utah National Guard, Operations Briefing. Draper, Utah: 1997.

Mendel, William S. and Murl D. Munger. StrategiC Planning and the Drug Threat: Strategic Studies Institute, U.S. Army War College, 1997. 
National Guard Bureau Counterdrug Directorate Budget Briefing. Alexandria, Virginia: 1997.

National Guard Bureau Flight Hour Mission Briefing. Alexandria, Virginia: undated.

Newberry, Robert J. Policy Memorandum Titled: "Preparation of Fiscal Year 1999/2000 National Guard Counterdrug Governor's State Plans and Other National Guard Programs." Washington D.C.: 1997.

Office of the National Drug Control Policy. The National Drug Control Strategy 1997. Washington D.C.: U.S. Government Printing Office, 1997.

Oklahoma Army National Guard Aviation Support Interview with Colonel Leroy A. Wall. Oklahoma City, Oklahoma: 1997.

Tennessee National Guard Marijuana Eradication Interview with Colonel Chester M. Waggoner. Nashville, Tennessee: 1998.

Tennessee National Guard Marijuana Eradication Overview Briefing. Nashville, Tennessee: 1998.

Texas National Guard Counterdrug Information Booklet (Port of Entry Operations). Laredo, Texas: undated.

Texas National Guard Counterdrug Interview with Lieutenant Colonel Gladys R. Tinsley. Austin, Texas: 1997.

Texas National Guard Counterdrug Program Information Paper. Austin, Texas: 1998.

Texas National Guard Counterdrug Special Operations Detachment Briefing. Austin, Texas: 1997.

United States Code, Title 32, Section 112, 1998.

West, Togo D., Jr. and Dennis J. Reimer. A Statement on the Posture of the United States Army Fiscal Year 1998. Washington D.C.: Headquarters, Department of the Army, 97. 